\title{
Anti-Inflammatory Effects of Rosmarinus officinalis Essential Oil in Mice
}

\author{
Štefan Juhás, Alexandra Bukovská, Štefan Čikoš, Soňa Czikková, Dušan Fabian, \\ Juraj Koppel
}

Institute of Animal Physiology, Slovak Academy of Sciences, Košice, Slovak Republic

Received June 9, 2008

Accepted October 1, 2008

\begin{abstract}
Essential oils are plant secondary metabolites possessing various pharmacological properties, primarily anti-oxidative, antimicrobial or immunomodulative, but they can exhibit toxic and allergic effects as well. The aim of this study was to compare the effects of Rosmarinus officinalis essential oil dietary administration in carrageenan paw oedema and trinitrobenzene sulfonic acid (TNBS) colitis. ICR mice received rosemary essential oil at three concentrations (1 250, 2500 and $5000 \mathrm{ppm}$ ) in the standard laboratory diet starting two weeks before the experiments. The inflammation of paws induced by carrageenan application was evaluated by measurement of paw swelling, paw weight and myeloperoxidase activity. In the TNBS model the mice were killed by cervical dislocation 3 days after colitis induction and the mortality, changes in the body weight of mice, colon weight : body weight ratio, macroscopical scores and myeloperoxidase activity were analysed. Furthermore, IL-1 $\beta$ and IL-6 cytokine levels in colonic tissue were quantified using ELISA assay. Dietary supplementation with $5000 \mathrm{ppm}$ of rosemary essential oil initially after $2 \mathrm{~h}$ increased but after $24 \mathrm{~h}$ suppressed the extent of paw oedema. The same dose in the TNBS model exhibited protective effects on colonic mucosa and significantly decreased macroscopic scores for colonic inflammation. On the other hand, in colon samples from mice fed the diet with $1250 \mathrm{ppm}$ of rosemary essential oil we detected decreased myeloperoxidase activity and significantly lower levels of IL-6 compared to TNBS control animals.

Our results indicate that rosemary essential oil is able to influence several variables of murine experimental inflammatory models depending on the concentration used. We conclude that the anti-inflammatory effects of rosemary essential oil should be interpreted carefully due to its timeand dose-related effects.
\end{abstract}

Inflammation, TNBS colitis, carrageenan paw oedema, rosemary essential oil, cytokines

It is known that a large number of plant species contain various bioactive compounds that may have health-beneficial properties, anti-oxidative, anti-inflammatory and antimicrobial effects, and their preventive and therapeutic use is increasing. Various plant products have been already tested in different animal models of inflammation for the development of new preventive and curative remedies.

Carrageenan-induced mouse paw oedema has been widely used for analysis of the antiinflammatory effects of plant extracts and essential oils (Maruy ama et al. 2006; Fernandes et al. 2007; Juhás et al. 2008a). Experimental colitis in mice and rats induced by the administration of various chemical agents is frequently used to study various compounds as possible therapeutic agents for inflammatory bowel disease (Ikeda et al. 2008). The intrarectal application of trinitrobenzene sulfonic acid (TNBS) produces severe necrotic lesions that heal after several weeks and leave scars and fibrosis as sequelae. Moreover, this model of colitis significantly increased IFN- $\gamma$ levels in colonic samples only (PérezNavarro et al. 2005). Currently used therapies of inflammatory bowel disease seem to be suboptimal and consequently different complementary and alternative medicines are used for symptom relief and improved quality of life. Accordingly, many of these alternative therapies are able to modulate the immune system and disrupt the proinflammatory cascade through a variety of mechanisms, including antioxidant effects, alterations in 
cell signalling (in particular the NF- $\mathrm{BB}$ pathway), cytokines, proinflammatory mediators, and disruption of bacterial flora (Clarke and Mullin 2008). These alternative treatments include herbal therapy consisting of anti-oxidant, anti-inflammatory and antimicrobial plants administration, too. We have described very recently that thyme essential oil in the diet was able to attenuate murine TNBS-induced colitis depending on the concentration used (Juhás et al. 2008a).

Rosmarinus officinalis is known as a common herb and household plant broadly used all around the world for different medicinal purposes, being a component of various established anti-inflammatory plant drug preparations, and having a long tradition of use for treating headaches, colds and colic, as well as other diseases (Darshan and Doreswamy 2004). Anti-oxidant properties of rosemary and their compounds have been confirmed recently (Cheung and Tai 2007; Atsumi and Tonosaki 2007); furthermore, rosemary extracts and their triterpenes (ursolic acid, oleanolic acid and micromeric acid) have been shown to exert anti-inflammatory activity in vivo (Altinier et al. 2007).

Up to now only a few studies have analysed the effects of rosemary or its essential oil on the gastrointestinal apparatus (Galisteo et al. 2000). Our aim therefore was to examine whether the dietary addition of rosemary essential oil could have positive effects in experimental intestinal inflammation induced by TNBS administration in mice.

\section{Materials and Methods}

Animals and treatment

Weight-matched ICR mice (5-6-week-old males from the Institute's breeding facility, weighing 28-32 g) were randomized into groups. The organization of the experiment, the investigations conducted, and the related documentation complied fully with legislative regulations governing the protection of experimental animals in the Slovak Republic. All animal experimentation was reviewed and approved by the Ethics Committee of the Institute of Animal Physiology.

Rosmarinus officinalis essential oil (Ph. Eur. 4) purchased from Calendula, a.s. (Nová Lubovňa, Slovakia, lot 5-014-009-12-06, containing approx. 25\% cineole, 19\% $\alpha$-pinene, 19\% camphor, $17 \% p$-cymene, $9 \%$ camphene, $5 \% \beta$-pinene and $2 \%$ borneol) was added to powdery commercial rodent diet (Diet for laboratory mice and rats SPF, M1; František Machal, Ricmanice, Czech Republic) in 1\% edible soy oil (Brölio, Germany) at the following concentrations: 5000 ppm (wt/wt) - group A; 2500 ppm (wt/wt) - group B; 1250 ppm (wt/wt) - group C. The diet for control and sham groups was prepared similarly using only $1 \%$ edible soy oil. The diets were fed ad libitum during the experimental period starting 14 days before administration of TNBS enemas. The mice of experimental group D were treated with dexamethasone (DEXAMED, Medochemie Ltd., Limassol, Cyprus) at a dose of $3 \mathrm{mg} / \mathrm{kg}$ b.w. s.c. $2 \mathrm{~h}$ before carrageenan application (paw oedema model) or $0.25 \mathrm{mg} / \mathrm{kg}$ b.w. s.c. starting $2 \mathrm{~h}$ before TNBS instillation, and then every $24 \mathrm{~h}$ until the sacrifice of the animals. Dexamethasone has anti-inflammatory effects and attenuates the enhanced neutrophil infiltration in many animal inflammatory models including carrageenan paw oedema and TNBS colitis.

Carrageenan paw oedema

Male ICR were anaesthetized with the mixture [ketamine 5\% (42.5\%)/ xylasine 2\% (7.5\%) / NaCl $0.9 \%$ $(50 \%)]$ at $60 \mu \mathrm{l} / 20 \mathrm{~g}$ body weight i.p. Each group of animals received subplantar administration of $50 \mu \mathrm{l}$ of saline to the left paw or $50 \mu \mathrm{l}$ of carrageenan $1 \%(\mathrm{w} / \mathrm{v})$ (SIGMA, Steinheim, Germany) in saline to the right paw. The volume was measured using a Mitutoyo thickness gauge (Mitutoyo, No. 7313, Japan) immediately before subplantar injection, and 2, 4, $24 \mathrm{~h}$ thereafter. The increase in paw volume was calculated as the difference between the right paw volume (carrageenan) and the left paw volume (saline) measured at each time point. The mice were killed by cervical dislocation after the last time point $(24 \mathrm{~h})$ and the carrageenan paws were rapidly amputated at the tarsocrural joint and weighed on an analytical balance.

Induction of TNBS colitis

Mice were anaesthetized with the mixture [ketamine 5\% (42.5\%)/ xylasine $2 \%(7.5 \%) / \mathrm{NaCl} 0.9 \%(50 \%)$ ] at $60 \mu \mathrm{l} / 20 \mathrm{~g}$ body weight i.p. and colitis was induced by intrarectal administration of $120 \mathrm{mg} / \mathrm{kg}$ of the hapten reagent TNBS (Fluka, Steinheim, Germany) in 50\% ethanol, and they were then kept in a vertical head-down position for $30 \mathrm{~s}$. The sham group received $50 \%$ ethanol alone through the same technique. The total injection volume was $40 \mu \mathrm{l}$. Development of colitis was assessed daily by the measurement of body weight. The mortality rate was observed during this study. Mice were killed by cervical dislocation 3 days after TNBS administration. Afterwards the colons were removed, opened longitudinally and cleared of faecal material with a gentle spray of $0.9 \%$ saline solution. The extent of mucosal damage was assessed using the colon macroscopic scoring system (Bukovská et al. 2007, adapted from Wallace et al. 1989). 


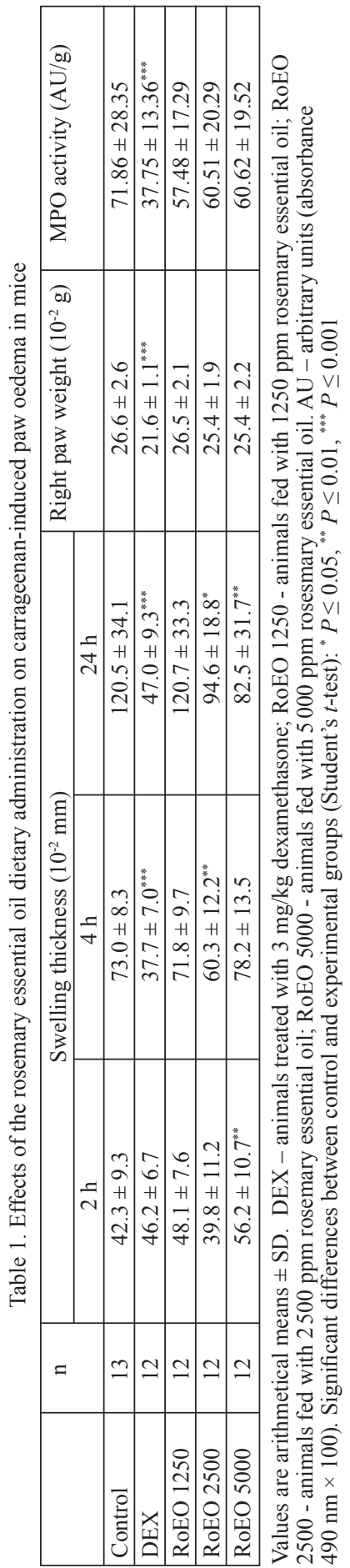

Ulceration: 1 - focal hyperaemia, no ulcer; 2 - ulceration, no hyperaemia/bowel wall thickening; 3 - ulceration, inflammation at one site; 4 - ulceration, inflammation at 2 or more sites; 5 - major injury $>1$ $\mathrm{cm} ; 6$ - 10 major damage $>2 \mathrm{~cm}$.

Adhesion: 1 - minor (colon easily separated from other tissue); 2 major.

Diarrhoea: 1.

Bowel wall thickening: 1 .

After scoring, the detached colon was dried and weighed. The colon weight/body weight ratio was calculated as a marker of colonic inflammation. Immediately after weighing, the macroscopically most intensively affected segment was cut for assessment of IL-1 $\beta$ and IL-6 protein expression and myeloperoxidase activity.

Myeloperoxidase (MPO) analysis

Myeloperoxidase activity correlates directly to the degree of neutrophil infiltration in the tissues. Samples (40-60 mg) of paws (carrageenan) or colonic samples (TNBS colitis) were homogenized on ice in $50 \mathrm{mM}$ of phosphate buffer ( $\mathrm{pH}$ 6.0) containing $0.5 \%$ hexadecyltrimethylammonium bromide. After freezing and thawing for three cycles, samples were sonicated $(90 \mathrm{~s})$ and then centrifuged at $12000 \mathrm{~g}$ at $4{ }^{\circ} \mathrm{C}$ for $30 \mathrm{~min}$. The supernatant was diluted with distilled water $(1: 10)$. The MPO activity of the diluted supernatant $(50 \mu 1)$ was assessed in 96-well plates (Gama group a.s., Trhové Sviny, Czech Republic). Supernatant aliquots were added to $50 \mu \mathrm{l}$ of the reaction mixture, which contained citrate buffer $\left(1.8405 \mathrm{~g} \mathrm{Na}_{2} \mathrm{HPO}_{4}, 0.511 \mathrm{~g}\right.$ citric acid, $0.01 \mathrm{~g}$ menthiolate in $100 \mathrm{ml}$ of distilled water), $4.62 \mathrm{mM}$ of 1 ,2phenylenediamine, and $4.76 \mathrm{mM}$ of $\mathrm{H}_{2} \mathrm{O}_{2}$ solution. MPO activities are presented as arbitrary units per $\mathrm{g}$ of paws or $\mathrm{mg}$ of colonic tissue. The enzyme activity was determined spectrophotometrically at 490 $\mathrm{nm}$ on a Microplate Spectrophotometer $\mu$ Quant (BioTek Instruments, Winooski, VT, USA).

Quantification of cytokine protein using ELISA

Colon tissue samples $(20-30 \mathrm{mg})$ were snap frozen in liquid nitrogen and stored at $-70{ }^{\circ} \mathrm{C}$. They were homogenized in $800 \mu$ l of ice-cold PBS containing protease inhibitor P8340 (Sigma-Aldrich, Munich, Germany) and the homogenates were centrifuged at $12000 \times g$ at $4{ }^{\circ} \mathrm{C}$ for $15 \mathrm{~min}$. Total protein in the tissue supernatants was determined using Bradford protein assay (Bradford 1976) with BSA as the standard. IL-1 $\beta$ and IL-6 concentrations were determined using ELISA assay, according to the manufacturer's instructions (Endogen, Pierce Biotechnology, Inc., Rockford, USA) on a Microplate Spectrophotometer $\mu$ Quant (BioTek Instruments, Winooski, VT, USA).

\section{Statistical analysis}

The results are expressed as means $\pm \mathrm{SD}$. Kruskal-Wallis and MannWhitney $U$ tests were used for macroscopic damage scores. ANOVA and Duncan tests were applied for IL- $1 \beta$ and IL-6 concentrations using ELISA assay. The Chi-square test was used to analyse differences in mortality rate. Student's $t$-test was used for differences in paw width and weight, the colon weight: body weight ratio and MPO enzyme activities. Values of $P<0.05$ were considered significant.

\section{Results}

\section{Mouse paw oedema}

As early as the first measurements, $2 \mathrm{~h}$ after induction of paw oedema, we detected a significant increase in paw swelling in mice fed the diet with 5000 ppm of rosemary essential oil (RoEO), compared to control mice $(P<$ 0.01 , Table 1$)$. In contrast to this, $24 \mathrm{~h}$ after carrageenan administration we observed a significant reduction in paw 


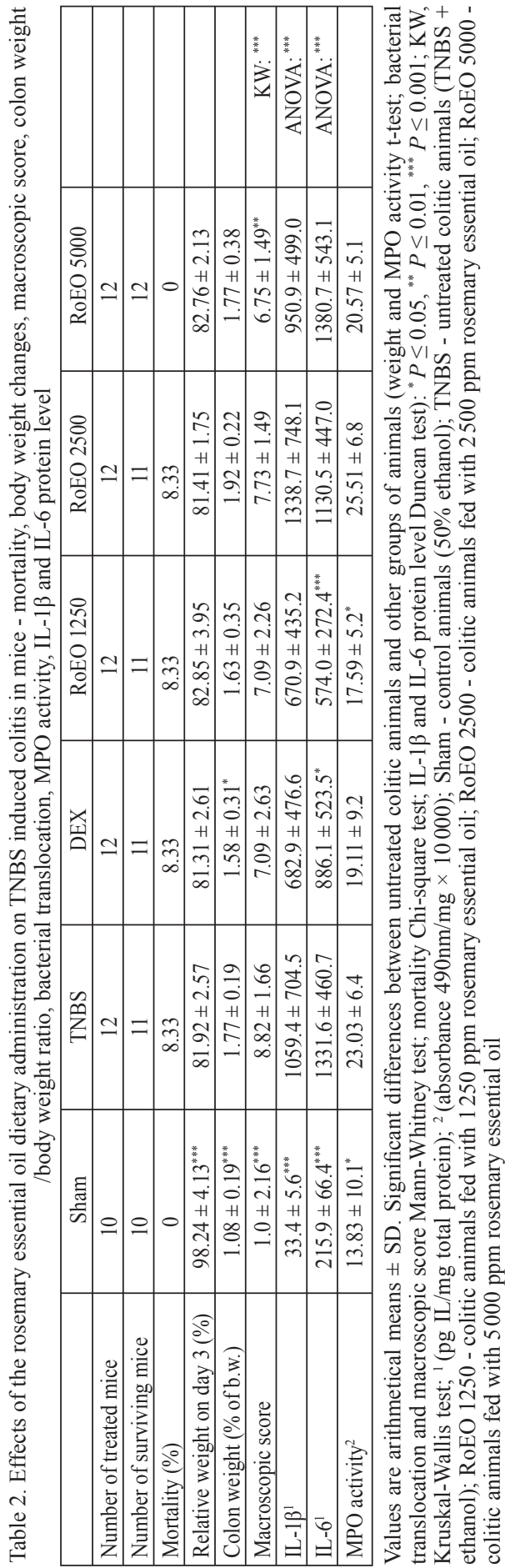

oedema $(P<0.01)$. Mice fed with a lower (2 $500 \mathrm{ppm}$ ) concentration of RoEO in the diet demonstrated a significant decrease in paw oedemas at later measurement points (4h $P<0.01,24 \mathrm{~h} P<0.05$ ), similarly as in the dexamethasone-treated $(3 \mathrm{mg} / \mathrm{kg})$ group where paw swelling was significantly reduced compared to the control group (4 h $P<0.001,24 \mathrm{~h} P<0.001)$. Paw weight and MPO activity of mice on diets with all three RoEO concentrations were decreased in comparison with control mice, but not significantly. We detected a significant decrease in paw weight $(P<0.001)$ and MPO activity $(P<0.001)$ in the dexamethasonetreated mice compared to controls.

TNBS induced colitis

The macroscopic damage scores and colon weight: body weight ratio of intact mice and mice in the sham group were significantly lower than that of mice in the TNBS group $(P<0.001$, Table 2$)$. Colon weight : body weight ratios in mice fed all concentrations of rosemary essential oil in diet were comparable with mice in the TNBS group. Treatment with dexamethasone caused a significant decrease in the colon weight : body weight ratio compared to the control TNBS group $(P<0.05)$. In contrast to this, the dexamethasone medication apparently did not protect the colon mucosa and we observed only a moderate non-significant decrease of macroscopic scores. RoEO addition to the diet induced a decrease in macroscopic scores, but the changes were not significant in groups on $1250 \mathrm{ppm}$ and 2500 ppm RoEO-enriched diet compared to the control TNBS group. However, the macroscopic scores of the group on 5000 ppm RoEO diet were significantly lower than those of the control mice (TNBS group) $(P<0.01)$.

Sham mice receiving only $50 \%$ ethanol intrarectally showed a significant reduction in MPO activity $(P<0.05)$ as well as lower concentrations of IL-1 $\beta$ and IL-6 $(P<0.001)$ in colon samples compared to the TNBStreated mice (Table 2). In the group treated with dexamethasone $(0.25 \mathrm{mg} / \mathrm{kg} / \mathrm{day})$, the colon MPO activity and IL- $1 \beta$ concentration 
decreased in comparison with the control mice (TNBS) group, but the changes were not significant. In contrast, the levels of IL-6 protein in the colon were markedly reduced by dexamethasone treatment $(P<0.05)$. In the TNBS group and groups on the diets with 5000 and $2500 \mathrm{ppm}$ of RoEO, the MPO activities and concentrations of IL- $1 \beta$ and IL-6 protein in colon samples were comparable. However, we observed a significant reduction in colon MPO activity $(P<0.05)$ and IL-6 protein $(P<0.001)$ in mice on the $1250 \mathrm{ppm}$ RoEOenriched diet compared to the untreated mice in the TNBS group.

\section{Discussion}

We analysed the anti-inflammatory effects of dietary administration of Rosmarinus officinalis essential oil in mice using carrageenan-induced mouse paw oedema and TNBSinduced colitis. A single dose of TNBS administered at the start of the experiment resulted in an acute local inflammatory response. Our results show that rosemary essential oil at a high concentration $(5000 \mathrm{ppm})$ in the diet was able to attenuate the colon inflammation as proved by the decreased macroscopic score. These facts could be hypothetically related to a synergy of biologically active compounds of rosemary essential oil, in particular their antiinflammatory as well as antimicrobial, anti-oxidative effects (Bozin et al. 2007), because luminal bacterial microflora plays an important role in the pathogenesis of TNBS-induced colitis in mice. In the paw oedema model we observed that higher concentrations of RoEO (5 000 and $2500 \mathrm{ppm}$ ) in the diet decreased mice paw oedema $24 \mathrm{~h}$ after carrageenan application. However, we detected the augmentation of paw oedema in mice treated with $5000 \mathrm{ppm}$ RoEO in the diet $2 \mathrm{~h}$ after carrageenan application. It could be speculated that the highest concentration of RoEO (containing eucalyptol, $\alpha$-pinene and borneol) inhibited acetylcholinesterase (Savelev et al. 2003) and produced vascular relaxation and plasma leakage during the first hours after carrageenan application (Ghisdal et al. 2005).

Rosmarinus officinalis essential oil contains a rich mixture of terpenes; in our preparation the most represented compound was 1.8-cineole (eucalyptol), which is known to have anti-inflammatory and antinociceptive effects (Santos and Rao 2000; Juergens et al. 2003). Therapeutic concentrations of cineole significantly inhibited cytokine production in lymphocytes (TNF- $\alpha$, IL-1 $\beta$, IL-4 and IL-5) and in monocytes (TNF- $\alpha$, IL-1 $\beta$, IL-6 and IL-8) with smaller effects on chemotactic cytokines (Juergens et al. 2004). Interestingly IL-6(-/-) mice compared with the wild-type mice, had significantly reduced intestinal inflammation as evidenced by epithelial damage, neutrophil infiltration, colon thickness and proinflammatory cytokine expression, following treatment with TNBS (Gay et al. 2006). Moreover, Santos et al. (2004) demonstrated that cineole administered by intrarectal instillation has therapeutic effects on TNBS-induced colitis in rats. In animals pre-treated (but not treated after TNBS administration), cineole significantly reduced the gross damage scores, wet weights $(\mathrm{mg} / \mathrm{cm})$ and myeloperoxidase activity of colonic segments. These data support our results indicating the protective effects of preventative rosemary essential oil in diet in TNBS colitis. At least two other components of this essential oil, $\alpha$-pinene and borneol, could also be involved in the biological effects of rosemary essential oil. In a dose-related fashion, $\alpha$-pinene inhibits the nuclear translocation of NF-kappa B induced by LPS in THP-1 cells (Zhou et al. 2004). TNBS-induced colitis in mice could be attenuated by antisense oligonucleotides inhibiting the p65 subunit of NF- kappa B, which suggests a critical role for NF- kappa B in mediating inflammatory responses (Kawada et al. 2007). We have shown very recently (Juhás et al. 2008b) that borneol (900 and $1800 \mathrm{ppm}$ in diet) was able to suppress significantly proinflammatory cytokines (IL-1 $\beta$ and IL-6) mRNA expression in TNBS colitis, although no significant morphological changes were detected. Similarly to the above experiments, in this study we have demonstrated reduced levels of IL-1 $\beta$ (non-significant) and IL-6 (significant changes) protein in the colon tissue in the group fed with $1250 \mathrm{ppm}$ of rosemary essential oil in the diet compared to the TNBS 
control group. Anti-inflammatory effects of $1250 \mathrm{ppm}$ of rosemary essential oil were confirmed also by the apparent decrease of neutrophil infiltration at the site of colonic inflammation reflected in the lower MPO activity.

Our study indicates that rosemary essential oil dietary application is able to affect murine experimental inflammatory models depending on the concentration used. Obviously, it is necessary to study in greater detail the immunomodulatory properties of rosemary extracts. We conclude, however, that the anti-inflammatory effects of rosemary essential oil should be interpreted with caution, due to its contradictory dose-related effects.

\section{Protizápalové účinky éterického oleja z Rosmarinus officinalis u myší}

Éterické oleje sú sekundárne metabolity rastlín, ktoré majú rozličné farmakologické vlastnosti, v prvom rade antioxidačné, antimikrobiálne alebo imunomodulačné, ale môžu tiež spôsobovat' toxické a alergické účinky. Ciel'om tejto štúdie bolo porovnat' účinky éterického oleja $\mathrm{z}$ Rosmarinus officinalis podávaného $\mathrm{v}$ krmive na edém labky vyvolaný karagenanom a kolitídu indukovanú podaním kyseliny trinitrobenzénsulfónovej (TNBS). Myši kmeňa ICR boli kŕmené štandardnou laboratórnou diétou s prídavkom rozmarínového éterického oleja $\mathrm{v}$ troch koncentráciách $(5000,2500$ a $1250 \mathrm{ppm})$ dva týždne pred začiatkom experimentu. Zápal labiek indukovaný aplikáciou karagenanu bol hodnotený meraním opuchu labiek, hmotnost'ou labiek a aktivitou myeloperoxidázy. V TNBS modeli boli myši usmrtené cervikálnou dislokáciou 3 dni po indukcii kolitídy, pričom boli analyzované mortalita, zmeny telesných hmotností myší, pomer hmotnosti hrubého čreva a telesnej hmotnosti myší, makroskopické skóre a aktivita myeloperoxidázy. Navyše boli kvantifikované koncentrácie cytokínov IL-1 $\beta$ a IL-6 v tkanive hrubých čriev pomocu ELISA kitu. Diéta s 5000 ppm rozmarínového éterického oleja na začiatku po $2 \mathrm{~h}$ vyvolala zväčšenie ale po $24 \mathrm{~h}$ zmenšenie rozsahu opuchu labky. Rovnaká dávka $\mathrm{v}$ modeli TNBS kolitídy mala ochranné účinky na mukózu kolónu a signifikantne znížila makroskopické skóre zápalu hrubého čreva indukovaného TNBS. Na druhej strane sme v porovnaní s TNBS kontrolnými zvieratmi zistili zníženie aktivity enzýmu myeloperoxidázy a signifikantne nižšiu koncentráciu IL-6 vo vzorkách hrubého čreva myší kŕmených s 1250 ppm koncentráciou rozmarínového éterického oleja v krmive. Naše výsledky svedčia o tom, že rozmarínový éterický olej v krmive môže ovplyvnit' niektoré parametre experimentálnych modelov zápalu u myší v závislosti na dávke. Protizápalové účinky rozmarínového etérického oleja je potrebné interpretovat' opatrne vzhl'adom na ich závislost' na čase a použitej dávke.

\section{Acknowledgement}

This work was supported by the Slovak Research and Development Agency under contract No. APVT-51015404 and by the State Program of Science and Development (SP 51/028 09 00/028 0906 )

\section{References}

Altinier G, Sosa S, Aquino RP, Mencherini T, Della Loggia R, Tubaro A 2007: Characterization of topical antiinflammatory compounds in Rosmarinus officinalis L. J Agric Food Chem 55: 1718-1723

Atsumi T, Tonosaki K 2007: Smelling lavender and rosemary increases free radical scavenging activity and decreases cortisol level in saliva. Psychiatry Res 150: 89-96

Bozin B, Mimica-Dukic N, Samojlik I, Jovin E 2007: Antimicrobial and antioxidant properties of rosemary and sage (Rosmarinus officinalis L. and Salvia officinalis L., Lamiaceae) essential oils. J Agric Food Chem 55: 7879-7885

Bradford MM 1976: A rapid and sensitive method for the quantitation of microgram quantities of protein utilizing the principle of protein-dye binding. Anal Biochem 72: 248-254

Bukovská A, Čikoš Š, Juhás Š, Il'ková G, Rehák P, Koppel J 2007: Effects of a combination of thyme and oregano essential oils on TNBS-induced colitis in mice. Mediat Inflamm 2007: 23296

Cheung S, Tai J 2007: Anti-proliferative and antioxidant properties of rosemary Rosmarinus officinalis. Oncol Rep 17: $1525-1531$ 
Clarke JO, Mullin GE 2008: A review of complementary and alternative approaches to immunomodulation. Nutr Clin Pract 23: 49-62

Darshan S, Doreswamy R 2004: Patented antiinflammatory plant drug development from traditional medicine. Phytother Res 18: 343-357

Fernandes ES Passos GF, Medeiros R, Da Cunha FM, Ferreira J, Campos MM, Pianowski LF, Calixto JB 2007: Anti-inflammatory effects of compounds alpha-humulene and (-)-trans-caryophyllene isolated from the essential oil of Cordia verbenacea. Eur J Pharmacol 569: 228-236

Galisteo M, Suárez A, Del Pilar Montilla M, Del Pilar Utrilla M, Jiménez J, Gil A, Faus MJ, Navarro M 2000: Antihepatotoxic activity of Rosmarinus tomentosus in a model of acute hepatic damage induced by thioacetamide. Phytother Res 14: 522-526

Gay J, Kokkotou E, O’Brien M, Pothoulakis C, Karalis KP 2006: Interleukin-6 genetic ablation protects from trinitrobenzene sulfonic acid-induced colitis in mice. Putative effect of antiinflammatory cytokines. Neuroimmunomodulation 13: 114-121

Ghisdal P, Vandenberg G, Hamaide MC, Wibo M, Morel N 2005: The diacylglycerol lipase inhibitor RHC80267 potentiates the relaxation to acetylcholine in rat mesenteric artery by anti-cholinesterase action. Eur $\mathrm{J}$ Pharmacol 517: 97-102

Ikeda M, Takeshima F, Isomoto H, Shikuwa S, Mizuta Y, Ozono Y, Kohno S 2008: Simvastatin attenuates trinitrobenzene sulfonic acid-induced colitis, but not oxazalone-induced colitis. Dig Dis Sci 53: 1869-1875

Juergens UR, Dethlefsen U, Steinkamp G, Gillissen A, Repges R, Vetter H 2003: Anti-inflammatory activity of 1.8-cineol (eucalyptol) in bronchial asthma: a double-blind placebo-controlled trial. Respir Med 97: 250-256

Juergens UR, Engelen T, Racké K, Stöber M, Gillissen A, Vetter H 2004: Inhibitory activity of 1.8-cineol (eucalyptol) on cytokine production in cultured human lymphocytes and monocytes. Pulm Pharmacol Ther 17: 281-287

Juhás Š, Bujňáková D, Rehák P, Čikoš Š, Czikková S, Veselá J, Il'ková G, Koppel J 2008a: Anti-inflammatory effects of thyme essential oil in mice. Acta Vet Brno 77: 327-334

Juhás Š, Čikoš Š, Czikková S, Veselá J, Il'ková G, Hájek T, Domaracká K, Domaracký M, Bujňáková D, Rehák P, Koppel J 2008b: Effects of borneol and thymoquinone on TNBS-induced colitis in mice. Folia Biol-Prague 54: $1-7$

Kawada M, Arihiro A, Mizoguchi E 2007: Insights from advances in research of chemically induced experimental models of human inflammatory bowel disease. World J Gastroenterol 13: 5581-5593

Maruyama N, Ishibashi H, Hu W, Morofuji S, Inouye S, Yamaguchi H, Abe S 2006: Suppression of carrageenanand collagen II-induced inflammation in mice by geranium oil. Mediat Inflamm 2006: 62537

Pérez-Navarro R, Ballester I, Zarzuelo A, Sánchez de Medina F 2005: Disturbances in epithelial ionic secretion in different experimental models of colitis. Life Sci 76: 1489-1501

Santos FA, Rao VS 2000: Antiinflammatory and antinociceptive effects of 1.8-cineole a terpenoid oxide present in many plant essential oils. Phytother Res 14: 240-244

Santos FA, Silva RM, Campos AR, De Araújo RP, Lima Júnior RC, Rao VS 2004: 1.8-cineole (eucalyptol), a monoterpene oxide attenuates the colonic damage in rats on acute TNBS-colitis. Food Chem Toxicol 42: $579-584$

Savelev S, Okello E, Perry NS, Wilkins RM, Perry EK 2003: Synergistic and antagonistic interactions of anticholinesterase terpenoids in Salvia lavandulaefolia essential oil. Pharmacol Biochem Behav 75: 661-668

Wallace JL, MacNaughton WK, Morris G, Beck PLl 1989: Inhibition of leukotriene synthesis markedly accelerates healing in a rat model of inflammatory bowel disease. Gastroenterology 96: 29-36

Zhou JY, Tang FD, Mao GG, Bian RL 2004: Effect of alpha-pinene on nuclear translocation of NF-kappa B in THP-1 cells. Acta Pharmacol Sin 25: 480-484 
